\title{
Why eight EU Member States signed, but not yet ratified the Convention for Human Rights and Biomedicine
}

\author{
Tom Goffin, Pascal Borry, Kris Dierickx, Herman Nys* \\ Centre for Biomedical Ethics and Law, Catholic University of Leuven, \\ Kapucijnenvoer 35, 7001, BE-3000 Leuven, Belgium
}

\begin{abstract}
The European Convention on Human Rights and Biomedicine was adopted by the Committee of Ministers of the Council of Europe on 19 November 1996 and opened for signature on 4 April 1997. At the moment 21 of the 33 countries that signed the Convention are EU Member States. Signing the Convention implies the obligation to put the Convention before the national Parliament within a reasonable period of time with a view to ratification. Eight of the 21 EU Member States - namely Finland, France, Italy, Latvia, Luxembourg, The Netherlands, Poland and Sweden - still have to complete the ratification.

In this article the reasons why eight Member States have not yet ratified the Convention, but only signed it, are mapped and analyzed. Because of the concrete list of patient rights provided for in the Convention, we focus on the question whether the reasons for not ratifying are related to these patient rights provisions.
\end{abstract}

(C) 2007 Elsevier Ireland Ltd. All rights reserved.

Keywords: Patient rights; Patient rights legislation; Convention on Human Rights and Biomedicine; Biomedicine Convention

\section{Introduction}

On 4 April 1997 representatives of 21 Member States of the Council of Europe signed the Convention for the Protection of Human Rights and Dignity of Human Beings with Regard to the Application of Biology and Biomedicine (hereafter the Convention) [1]. At the moment of signing 10 of these 21 were Member States of the European Union. After this opening for signature 12 other countries decided to sign the Con-

\footnotetext{
* Corresponding author. Tel.: +32 $16336949 / 51$; fax: +3216336952 .

E-mail address: herman.nys@med.kuleuven.be (H. Nys).
}

vention, which brings the total number on 33. At the moment 21 of these countries are EU Member States.

By signing the Convention, the process of ratification by the national authorities began and the obligation "to refrain, in good faith, from acts that would defeat the object and purpose of the Convention" was placed on these countries [2]. Moreover, signing the Convention implies the obligation to put the Convention before the national Parliament within a reasonable period of time with a view to ratification.

Already 13 of the 21 EU Member States - namely Bulgaria, Cyprus, Czech Republic, Denmark, Estonia, Greece, Hungary, Lithuania, Portugal, Romania, Slovakia, Slovenia and Spain - have finished their rati- 
fication process. These countries fulfilled the obligation provided for in article 1, Section 2 of the Convention and tried to make their internal law in conformity with it [3]. Eight countries - namely Finland, France, Italy, Latvia, Luxembourg, The Netherlands, Poland and Sweden - signed, but still have to complete the ratification.

The overall purpose of this article is to map and analyze the reasons why these eight States have not yet ratified the Convention. In particular, because of the concrete list of patient rights provided for in the Convention, we want to know whether the reasons for not ratifying are related to these patient rights provisions.

The structure of this article is as follows. Section 2 gives an overview of the Convention on Human Rights and Biomedicine itself. In Section 3 the legal differences between a signature and ratification are clarified and the consequences of signing are further explored. Section 4 explores the reasons why these countries did not ratify, and analyses for each of these Member States what their current position is regarding patient rights. Section 5 draws conclusions and contains some final remarks.

\section{The Convention on Human Rights and Biomedicine}

For several years now, the Council of Europe has concerned itself with the problems confronting mankind as a result of advances in medicine and biology. At the same time, a number of countries have done their own internal work on these topics, and this work is proceeding. So far, therefore, two types of endeavor have been undertaken, one at a national and the other at international level.

Because of the diversity in this field, a need was felt to harmonize and complete where necessary the existing national legislations concerning the application of biology and medicine. In July 1994, a first version of the draft Convention was subjected to public consultation and was submitted for an opinion to the Parliamentary Assembly of the Council of Europe. After 2 years of redrafting, the Convention was adopted by the Committee of Ministers on 19 November 1996. It was opened for signature in Oviedo, Spain, on 4 April 1997.

It sets out only the most important principles. The Convention as a whole will thus provide a com- mon framework for the protection of human rights and human dignity in both longstanding and developing areas concerning the application of biology and medicine [4]. The Convention is now of growing importance as a standard to evaluate the efforts and the progress made by the Member States of the European Union to promote and protect the rights of patients and users of health services [5].

The Convention contains 14 chapters. In the light of the objective of this article the following chapters are relevant: Chapters II and III of the Convention provide individual patient rights such as the right to consent, the right to information about one's health status and the right to private life. These rights are the main patient rights that should be guaranteed in every health care intervention. Chapter V: "Scientific Research" is also of importance here. As will become apparent later article 18 concerning the "research on embryos in vitro" is relevant [6].

\section{Legal difference between signing and ratifying the Convention}

"Ratification" and "signature" are both terms related to the process whereby a State indicates its interest in and its consent to be bound by a treaty. However, there is an important difference between both terms.

When a State signs a treaty, this signature is subject to ratification, acceptance or approval. By merely signing, the State has not yet expressed its consent to be bound by the treaty. However, a State that signs a treaty, is obliged to refrain, in good faith, from acts that would defeat the object and purpose of the treaty. Moreover this State is required to put the treaty before the national Parliament for ratification, acceptance or approval, thereby giving the people's representatives a direct say in the external activities of the State.

Unlike "signature" "ratification" refers to an act undertaken in the international sphere, whereby a State expresses its concrete consent to be bound by a treaty. Usually ratification involves two distinct procedural events. The first is related to the constitutional (internal) law of a contracting party. It involves the national procedure that must be fulfilled before the State can assume the international obligations enshrined in the treaty. In many instances this involves approval by the national Parliament. The second event deals with the 
external (international) level. It is the process through which the contracting party indicates its consent to be bound to the other contracting parties.

As the Convention on Human Rights and Biomedicine contains no provision deviating from these rules, they are also applicable on it.

\section{Reasons for not ratifying the Convention and the protection of patient rights}

As already mentioned 8 EU Member States signed the Convention, without having ratified it until now. It is remarkable that 7 of the 8 EU Member States signed the Convention already the day it opened for signature on 4 April 1997. Only Poland signed two years later, on 7 May 1999 [7]. Bearing the consequences of signing a Convention in mind, the puzzling question is why these countries did not ratify in a reasonable period after signing the Convention.

\subsection{Finland}

The main reason for the delay in ratification by Finland has to do with the constant failure to enact a law on assisted reproduction, a topic which is closely connected to the Convention, because article 18 regulates therapeutic cloning.

In a guideline of the National Advisory Board on Research Ethics on human stem cells, cloning and research the following statement on the process of ratification is given: "Finland's ratification of the Biomedicine Convention is expected to take place as soon as legislation on assisted reproduction has been introduced. Before ratification, Finland must consider its final approach to therapeutic cloning. If we accept therapeutic cloning, we must either make a reservation to article 18 of the Biomedicine Convention or make known the definition of the embryo as defined under Finnish law [8]". Another advisory board, the National Advisory Board on Health Care Ethics, stated in an opinion for the Ministry for Foreign Affairs regarding the Convention and its additional protocols that: "In Finland, for instance the Act on the Status and Rights of Patients, the Medical Research Act, the Act on Medical Use of Human Tissues and Organs, and the Mental Health Act are quite in line with both the Biomedicine Convention and its additional protocols. There are no provisions in legislation that would be contradictory to the Biomedicine Convention. Neither is it probable that provisions in contradiction with the Biomedicine Convention will be included in the law on infertility treatment which is being drafted at the Ministry of Justice. [...]". Although framed in another way, this statement does not deviate from the statement of the National Board on Research Ethics.

With regard to the definition of the embryo, the National Advisory Board on Health Care Ethics comments as follows: "The Finnish Medical Research Act defines that an embryo means a group of living cells resulting from fertilization, and according to this definition a cell tissue resulting from nuclear transplantation would not be an embryo. At least a notification of this should be made when ratifying the Biomedicine Convention (Article 18) [9]." (Italic by authors) Also this is in line with the proposal of the other Advisory Board to make known the definition of the embryo as defined under Finnish law.

On 22 December 2006 the Law on Assisted Reproduction was accepted by the Finnish Parliament. It will come into force as of 1 September 2007 [10].

Because of the acceptance of this law, and the fact that the absence of this law was the justification for not ratifying, the ratification could proceed in 2007 [11].

Despite the fact that Finland did not ratify, national legislation on patient rights is already in conformity with the Convention. This can be deduced from the above cited opinion of the National Advisory Board on Health Care Ethics. Moreover, this is the result of a deliberate policy. The intention to bring all laws old and new - concerning patient rights systematically in conformity with the Convention can also be read in an earlier opinion of the National Advisory Board on Health Care Ethics on some amendments on the Act on the Status and Rights of Patients: "It should therefore be carefully considered what kind of changes the Convention on Human Rights and Biomedicine of the Council of Europe requires to be made to the original Finnish Patient Act [12]."

In Finland patient rights are protected by several laws: specific patient rights legislation and general statutory provisions regarding health care. The most significant is the Act on the Status and Rights of Patients (No. 785/1992). This law, which is the world's first patient rights act, regulates several rights of 
patients, such as the right to information, the right to self-determination, the maintenance of patient records, etc [13]. Other significant acts are the Act on the Status and Rights of Social Welfare Clients (No. 812/2000), which provides very similar rights as the Patient Rights Act and the Act on Patient Injuries (No. 585/1986), which focuses on financial compensation for patients in case of medical damage.

\subsection{France}

France signed the Convention the day it opened for signature. The text of the Convention is partly inspired by the French Acts on Bioethics of 1994 [14]. Although because of this "inspiration" there were from the very beginning a lot of parallels between French law and the Convention, France did not ratify it [15]. In a speech during the General Conference of UNESCO on 14 October 2003, the then President of France, Jacques Chirac, gave the following explanation for the non-ratification: "The drafting of the Oviedo Convention can be used as a model. This instrument has now entered into force and provides the terms of reference for defining European rules and developing national bioethical standards. France will complete the process of ratifying the Convention, after amending its own bioethics legislation at the end of the year" [16]. (Italic by authors) The will to ratify was repeated by the then Minister of Health Jean-François Mattéi and his successor, Phillipe Douste-Blazy in the preparatory debates of the Act on Bioethics of 2004 [17]. On 6 August 2004 this Act which revised the Acts on Bioethics of 1994, was approved by the French Parliament. Although this revision was the only reason given for not ratifying, the ratification process did not start after it.

Currently the Act on Bioethics of 2004 itself is being amended. More in particular, article 22 - concerning cloning - needs revision, because it does not include a prohibition of reproductive cloning. According to a report to the then Prime Minister on "Stem cells and ethical choices" of 2006 the ratification of the Convention will now take place together with a ratification of the Additional Protocol to the Convention concerning the prohibition of cloning [18].

On 4 March 2002 the Act No. 2002-303 concerning the rights of patients and the quality of the health system (amending among other things the Public Health Code and the Civil Code) was approved by the French Parliament. Patients' associations were active in promoting this Act. A redefinition of priorities by the government places from now on "the individual, the person, in other words the patient or the user, as the focus of concerns, at the centre of legislation: we must move from a system of professionals to a system directed towards the individual" [19]. The Act inserts a preliminary chapter in the Public Health Code entitled "Rights of the Individual". The Act includes three objectives. The first objective is to enhance patients' ability to use their "voice" in the health care system. A key emphasis hereby is put on individual rights for the patient. The words of article 1111-1 of the Public Health Code could not be clearer: "There can be no democratic health system without a corresponding legal framework of rights accorded to sick people and users." The second objective is to improve the quality of care and to develop continuing education for health care professionals and evaluation of professional practice. A third objective concerns the protection against the risks related to diagnostic and therapeutic procedures [20]. On 22 April 2005 the Act No. 2005-370 concerning the rights of patients and the end of life came into force. Like the Act of 2002, this Act amends in the first place the Public Health Code. Both Acts taken together, France disposes of extensively developed patient rights legislation.

\subsection{Italy}

On 28 March 2001, the Act No. 145, which ratified the Convention, was approved by the Italian Parliament, with a majority of 386 for, 3 against and 13 abstentions, although the Parliament was at that time already dissolved because of the forthcoming political elections [21]. This was not the only remarkable fact concerning the ratification in Italy. On the list of signatures and ratifications of the Convention on the website of the Council of Europe, Italy appears as one of the countries which only signed.

The ratification procedure of an international treaty has two phases: an internal and an external phase. The internal phase usually comprises the adoption by the Parliament of a law to authorize ratification of the treaty and the promulgation of that law by the Head of State. The external phase is constituted by the deposit of the instrument of ratification [22]. Because Italy has not yet deposited the instrument of ratification and as this is an 
essential part of the procedure according to article 33.4 of the Convention, Italy does not appear as a country which has ratified the Convention [23]. No reasons why Italy did not deposit the instrument of ratification, were found.

Patient rights in Italy are regulated by the Code on Medical Ethics. Because of the fact that this Code is not legally binding, "many in Italy, aspire to a more effective code of medical deontology which not only gives examples and advice but which also assumes the role of an actual law as happens in France where 'Le code de déontologie médicale' is a legislative act" [24]. Although there is no concrete patient rights legislation in Italy, this does not mean that no evolution can be noticed concerning patient rights and the adaptation of the legislation to the Convention. The Convention has played a major role in the discussions regarding the Act No. 40 of 19 February 2004 on medically assisted reproduction [25]. According to Fenton "the catalyst for legislating in 2004 was the ratification of the 1997 Oviedo Convention and subsequent Protocol in order to bring Italy into line with the principles of the Convention and the Protocol" [26]. In the deliberations concerning the admissibility of a popular referendum on Act No. 40 the Government argued for the inadmissibility of the referendary question because "the law contained norms adopted in light of international and European laws, or adopted in close connection to them (in particular the Oviedo Convention on Human Rights and Biomedicine of April 4, 1997 and its Additional Protocol No.168 of 12 January 1998 banning human cloning, both ratified and implemented domestically with law no 145 of 28 March 2001)" [27]. The Constitutional Court declared this request for a referendum inadmissible. Three requests for a partial repeal of Act No. 40 have been declared admissible [28].

\subsection{Latvia}

During a period of 50 years Latvia has been living under the Soviet regime. In this period human rights, personal dignity, and human autonomy where not protected by any law. The country regained its independence at the end of the twentieth century [29].

The procedure of ratification of the Convention started already in 2000 . The Act on ratification passed the first reading in Parliament in January 2001. In Octo- ber 2002 a new Parliament was elected, and it was therefore necessary to start the ratification procedure all over again. This second procedure for ratification started in Parliament in December 2002 and also passed the first reading. Since than no further development was found. There is no official answer why this is so.

Although Latvia has signed the Convention on 4 April 1997, its patient rights legislation is not well elaborated. The Latvian Constitution declares in article 111 that the State shall protect human health and guarantee a basic level of medical assistance for everyone [30]. Notwithstanding this article, Latvian Parliament seems not to be very active in this field. It has passed some laws, such as the Law on Medical Care, and the Law on Pharmaceuticals, but many health-related fields such as patient rights have not yet been covered by laws. The only regulations concerning patient rights can be found in a short chapter of the Law on Medical Care [31].

Acting as an expert for the World Health Organization, Lars Fallberg studied the patient rights situation in Latvia in 2003. One of his conclusions was the following: "It is very important to define by law in which cases a doctor or other health care specialist may be allowed to use force and similar methods, and when they may not." His report also included the need to specify by law the accountability of medical workers and to focus more on securing the protection of medical information, which is "a significant gap in the law, and it is unacceptable that the law does not protect the medical and personal information of health service users." According to Fallberg patients generally lack the opportunity to complain about the violation of their rights. Patients complained, according to Fallberg, mostly about the disorderly family doctor system, as well as the "unofficial money" relations between doctors and patients [32].

A draft law on Patients' Rights has passed first reading in Parliament in 2005. Since the spring of 2005 this draft is being revised. Fallberg also studied this draft Law and stated that "the draft law on the Rights of Patients has to be improved before it can be accepted by Parliament. The draft law consists of several weaknesses. It refers to other legal acts without mentioning any specific one. The draft law includes terms such as 'medical documents', 'medical persons' without defining them. Furthermore, the draft law lacks consistency 
and the various provisions are repeatedly overlapping each other. [...] Fundamental provisions are missing which makes it difficult to get an understanding of what values the legislator aims to protect with the draft law [33]."

In March 2007 a new visit by Fallberg to Latvia created a momentum. Proposals for a second reading of the draft Law are now being prepared. Fallberg repeated that there are still the same important problems of understanding and interpreting patient rights as there were in 2003 [34]. Although this statement may look rather negative, the understanding and interest in a Law on Patient Rights by members of Parliament, the Ministry and several doctors has changed for better, according to Liene Sulce, Director of the Patients' Rights Office of Latvia [35].

Another step forward is the Latvian Ombudsman, which was established on 1 January 2007 by the new Ombudsman Law. This institution can be of help in protecting patient rights [36].

\subsection{Luxembourg}

Luxembourg is one of the countries that already made considerable progress in the ratification process. On 2 February 2006 a proposal for an act on the ratification of the Convention was presented in Parliament [37] and this proposal was sent to the Council of State to receive its opinion. This opinion was made public on 4 April 2006. The Council of State noticed that the proposal was limited to the modification of the Act of 25 November 1992 on the removal of human tissues, to bring it in conformity with the Convention. Because of the fact that the ratification Act would have an important influence on "very wide and ethical complex issues" - such as the examination and manipulation of the human genome, the medical assisted procreation and the research on embryos for reproductive cloning - the Council of State proposed to delay the ratification of the Convention until these issues have been regulated in national legislation [38].

Reacting on this opinion the Government stated that there were more reasons to ratify, than to delay it. Its major argument was that because of the direct applicability of many articles in the Convention [39], these provisions would complete the national legislation on patient rights and the legislation on research on the human genome [40]. Since this Governmental reaction was made public on 30 May 2006, nothing more was heard on this issue.

Luxembourg does not have a specific patient rights Act. The Act on hospital establishments of 28 August 1998, contains in Chapter 10 a catalogue of important patient rights of which some are only applicable to the patients who are admitted in a hospital, while other rights are applicable to every patient [41]. A new Code of medical ethics has been adopted and approved by Ministerial Decree of 7 July 2005 [42]. This Code of medical ethics contains a specific Chapter IV about the relations between the doctor and the patient. This Code is legally binding.

In this respect we refer to a new constitutional provision adopted in 2004 stating that the bodies of a profession, such as doctors, provided for by law, may adopt binding rules for the members of the profession [43].

\subsection{Poland}

As one of few countries Poland abstained vote on the final text of the Convention on 19 November 1996 [44] and was from the beginning rather skeptical about the entire Convention [45]. Early reports from Polish debate on the Convention put forward that the Convention does not grant satisfactory protection of the fetus [46].

Poland is a country with one of the strongest standards in the protection of unborn life. It is protected from the moment of conception. Therefore Poland believes that the ban on therapeutic cloning in the Convention is not strong enough and leaves unacceptable loopholes by allowing it [47]. Contrary to this widely spread political opinion, the prevailing opinion of the Polish scientific community, which convened several conferences with foreign participation on the issues of genetics and bioethics, is that only reproductive cloning should be completely banned. The Code of Medical Ethics of 2004 further stipulates that a physician shall participate neither in the procedures of human cloning for reproduction or therapeutic purposes, nor in the acts aiming to provoke genetic changes in humans [48].

It is not probable that consensus will soon be reached between these diverging opinions [49]. Under these circumstances Poland might opt to develop a more restrictive domestic legislation, before ratifying the 
Convention. No legislative initiatives have been taken [50].

A way out of this impasse might be an initiative of the Ombudsman for Human Rights [51]. Because of the close connection of cloning with human rights this institution could present this topic as an important human rights issue on which effective regulation should be achieved as soon as possible. In that way, a public debate on these sensitive topics may be enabled.

Patient rights are regulated in many different legal acts. The most important one is the Act of 30 August 1991 on Health Care Institutions which was the first to specify the fundamental rights of patients. The general right to health care of every citizen is granted in article 68.1 of the Polish Constitution [52].

To enforce the position of the patient within the public health care system, there exists "The Office of Patient Rights and the institution of the Ombudsman of Patient Rights"[53]. After questions raised by the Polish Ombudsman on the topic of patient rights, the Ministry of Health presented a 'Charter of Patient Rights' in December 1998. The Charter provides a catalogue of patient rights with references to the corresponding legal basis, but in itself it is not a source of law. After 1998 several laws, providing patient rights, were amended and new regulations were adopted. Therefore the Charter cannot be considered as a document giving the complete picture about the legal protection of the patient in Poland.

\subsection{The Netherlands}

Between 1998 and 2002 some initiatives were taken to ratify the Convention, but no law came into force. In the years there after a fundamental conflict between article 18 of the Convention and the Act on Embryos of 20 June 2002 came to the surface.

Article 18 of the Convention prohibits the creation of human embryos for research purposes. The Act on Embryos also prohibits the creation of human embryos for such purposes, but this prohibition is only temporary. The Government can lift this prohibition and consequently make the creation of embryos for research purposes under strict conditions possible [54].

In 2004 the Government decided not to change the current legal situation during the governmental session.
The consequence of this decision was that during this session no use was made of the possibility to lift the prohibition. But also, the Government did not propose to change the Act on Embryos in order to prohibit the creation of embryos for research purposes, without any exceptions [55]. The ratification of the Convention is delayed until the Act on Embryos and the Convention itself have been evaluated [56].

Meanwhile a new Government was installed in the Netherlands. One may doubt whether during this new governmental session anything will change in this field. Until now no initiative has been taken in order to start the process of ratification.

The Netherlands is one of the pioneer countries when it concerns patient rights. The rights of patients have acquired their place in the Dutch legal system by the codification of the general rights of the patient in the Act on the medical treatment contract of 1 April 1995, as part of the Dutch civil code [57]. The main purpose of the Act is to clarify and strengthen the legal position of the patient.

The scope of the legal provisions on patient rights also extends to medical actions that are not performed in the frame of a contract in as far as the nature of the situation allows for the application of the provisions [58].

Because of the clear structure of this Act, several countries - such as Lithuania and Estonia - have based their Patient Rights Act on the Dutch Medical Contract Act [59].

\subsection{Sweden}

Sweden signed the Convention on 4 April 1997. According to a Government proposition 2002/03:50 in order to ratify the Convention ethically correct research requires necessarily a legally enforceable regulation in order to protect the participants [60]. This legislation is necessary because the Convention contains certain stipulations concerning the conduct and implementation of ethically correct research.

After the signing of the Convention, several adjustments have been made in Swedish law, partly in view of a future ratification. According to E. Rynning, Professor of Medical Law of the Uppsala University, three important acts were constructed to this end. These are the Act on Biobanks in Health Care of 2002, the Act on Ethical Review of Research Involving Humans of 
2003 and the Embryo Act of 2005 [61]. With regard to the Embryo Act a reservation will be necessary with regard to article 18.2 of the Convention because this act explicitly allows the creation of embryos for research while prohibiting reproductive cloning [62].

According to E. Rynning there are still several areas where Swedish law is not in conformity with the Convention among which the following two. Firstly there is a lack of a comprehensive system for proxy decisionmaking for incapacitated adults in health care and research. This was stated in a report of a Parliamentary Commission in December 2004 [63]. The Ministry of Health took this report into consideration, but no concrete solutions were found [64]. The second problem relates to human genetics and has been signaled in a report by the Committee on Genetic Integrity [65]. There is no prohibition of predictive testing for non health related purposes, nor is there any explicit prohibition of genetic discrimination. And the possibility of choosing the sex of a future child is not regulated [66].

The Committee proposed the introduction of new legislation in the form of an Act on Genetic Integrity, dealing with aspects related to Chapter IV-Human Genome, of the Convention. Not all aspects of the provisions of this Chapter are dealt with in the proposed Act, as the Committee presents a rather restrictive interpretation of the obligations prescribed in the Convention.

Sweden has no specific Patient Rights Act. Patient rights are promoted in different ways. In several acts - such as the Health and Medical Personnel Duties Act and the Code on Parents, guardians and children - patient rights are regulated in a rather specific way. The Federation of County Councils has issued a Charter which contains several principles for promoting patient rights based on existing legislation and agreements between the Federation of the County Councils and the State. This document was sent to all the county councils in order to shape in each county a patient rights policy based on the principles of this document. However, this document was not designed to provide legal rights enforceable in court nor can it be considered as a national charter [67].

In 1997, the official report "The Patient is Right" concluded that patient rights in Sweden are well protected, but the aim should be to propose a patient rights law within the next few years to come. In the mean time, however, a number of complementary provisions were proposed, which came into force in 1999 [68].

\section{Concluding remarks}

More than 10 years after having signed it, eight EU Member States did not ratify the Convention on Human Rights and Biomedicine. Because of the importance of this Convention for the harmonization of patient rights in the EU, the reasons for not ratifying were explored.

In the majority of these eight countries a remarkable change in policy concerning patient rights can be noticed. These policies are since the signing of the Convention directed towards conformity with the Convention. The obligation "to refrain, in good faith, from acts that would defeat the object and purpose of the Convention" is consequently being respected by most countries.

The eight Member States can be divided into three groups according to the reason for not ratifying:

- The countries that already changed their legislation in order to comply with article 1 Section 2 of the Convention and for which the way is free to ratify ("Ready to ratify");

- The countries that encounter problems with article 18 (embryo-research) of the Convention and that either will have to adjust their legislation, or will have to prepare a reservation based on article 36 of the Convention; problems with patient rights are not the (main) reason for not ratifying ("Problems with article 18").

- The countries for which ratifying the Convention causes major problems because of problems to provide sufficient protection for patient rights ("Problems with patient rights").

\subsection{Ready to ratify}

Finland and Luxembourg will probably ratify in the near future.

- Although Finland should also be mentioned in the second group of countries it will probably finalize the ratification process soon, because of the Law on Assisted Reproduction of 22 December 2006 which has been accepted in the Finnish Parliament and which will come into force as of 1 September 2007. 
- Because of the fact that Luxembourg is already in the process of producing an Act on the ratification of the Convention and the Government has made a strong opinion in favor of the ratification, the Convention will probably be ratified in the near future.

Finland is the only country of this group that has a concrete Patient Rights Act. Beside this Act patient rights in Finland are also protected in other laws.

Luxembourg protects patient rights through several laws in which certain patient rights are regulated. Generally spoken patient rights are well protected in these countries and are already very much in line with the Convention.

\subsection{Problems with article 18 of the Convention}

This is the largest group of Member States. It includes to a certain degree Finland and also France, The Netherlands, Poland and Sweden.

Each of these countries has made in one or another way a statement that it will ratify the Convention as soon as there is on a national level legal clarity on the compatibility of its legislation with article 18 of the Convention, concerning the creation of embryos for research purposes. Either they will have to adjust their national legislation in order to make it in conformity with the Convention, or they will have to make a reservation based on article 36 of the Convention concerning article 18.

As already pointed out Finland has meanwhile solved this problem by accepting the Law on Assisted Reproduction of 22 December 2006.

According to a report to the then Prime Minister on "Stem cells and ethical choices" of 2006 the ratification of the Convention by France will take place once the Act on Bioethics is revised and together with the ratification of the Additional Protocol to the Convention concerning the prohibition of cloning.

In the Netherlands the lifting of the temporary prohibition regarding the creation of embryos for research or its replacement by a definitive prohibition is to be awaited before the Dutch Parliament will ratify. Under the current Governmental Session no solution is to be expected. The ratification therefore might take quite some time in the Netherlands.

The ratification in Poland is not expected in the near future because of the major diversity in Poland concerning embryo research and other sensitive topics. Although a debate concerning the ratification would be a great opportunity of public discussion on several sensitive topics such as procreation or embryo research, such debate is not expected to take place in the near future.

The Embryo Act of 2 February 2005 explicitly allows the creation of embryos for research in Sweden. Although there seem to exist some minor contradictions between the Swedish legislation and the Convention, Sweden can ratify the Convention once it has decided on the reservation that needs to be made regarding article 18 .

Patient rights in these countries are guaranteed in different ways. France, the Netherlands and Finland all have specific patient rights legislation. In Poland and Sweden patient rights are protected in several acts, codes and patient rights directed policies. With the exception of Poland to a certain degree, patient rights in this group of countries as a whole are well protected and already very much in line with the Convention's patient rights policy.

\subsection{Problems with the Convention}

Two countries belong to this group: Italy and Latvia.

- Although Italy has already an Act that ratifies the Convention and the only thing needed is the deposit of the instrument of ratification by Italy at the Council of Europe in Strasbourg there are several reasons to believe that this may still last for a long time. Firstly, compared to the Convention the existing protection of patient rights in Italy is not well developed. Secondly Italy belongs to the countries with a so-called dualistic system so that adaptation of the national legislation before ratification is required. No such plans exist for the moment. And finally we should remember the odd circumstances in which the ratification Act was approved by Parliament.

- Because of the major problems that occur in Latvia concerning the Patient Rights Act - Latvia is a country that still has a large field to explore in protecting patient rights - and the ratification of the Convention as a whole, ratification will probably take several years in Latvia.

Although there are drafts of patient rights legislation, the Latvian legislator has to make some major 
changes in the national patient rights policy in order to make a respectable and effective patient rights act.

The ratification of the Convention on Human Rights and Biomedicine by the EU Member States is an important step in protecting patient rights in their countries and in the entire European Union, because it guarantees the most important rights on an effective level.

Still, ratification stays necessary to ensure a uniform system of patient rights protection in the whole European Union.

A positive result of the study of this article is that the reasons which where found for not yet ratifying, are in almost every country not patient rights related. Patient rights are relatively well protected on a national level and the national legislation is already often in conformity with the Convention on this field.

\section{Acknowledgments}

The research for this contribution was supported by the Eurogentest Network of Excellence of the EU, FP6512148.

We like to thank the following persons who supported us with information: Vittorio Fineschi, Maja Grzymkowska, Lena Jonsson, Mervi Kattelus, Raimo Lahti, Giusella Moscato, Solvita Olsena, Elisabeth Rynning, Sirpa Soini, Liene Sulce, Catoke Visser, Georges Wivenes and Karolina Ziêba.

\section{References}

[1] Convention for the Protection of Human Rights and Dignity of the Human Being with regard to the Application of Biology and Medicine, Oviedo, 4.IV; 1997. http://conventions.coe.int.

[2] Art. 18 Vienna Convention on the Law of Treaties.

[3] A study of the countries which already ratified the Convention can be found in Nys H, Stultiëns L, Borry P, Goffin T, Dierickx K, Patient Rights in EU Member States after the ratification of the Convention on Human Rights and Biomedicine. Health Policy 2007. 83 (2-3): 223-35.

[4] Explanatory report to the Convention, comments on the provisions of the Convention. p. 1-2.

[5] Nys H, Goffin T, Stultiëns L, Borry P, Dierickx K. Patient rights in the EU-Denmark, European Ethical-Legal Papers, No. 2. Leuven; 2007. p. 1. Available at www.cbmer.be.

[6] This article stipulates: (1) where the law allows research on embryos in vitro, it shall ensure adequate protection of the embryo. (2) The creation of human embryos for research purposes is prohibited.

[7] Latvia and Poland were no EU Member State at the moment they signed the Convention.

[8] Finnish National Ethics Committees: human stem cells, cloning and research. Helsinki, Finland; 2005. 20 pp., www.protsv.fi.

[9] National Advisory Board on Health Care Ethics, Request for opinion from the Ministry for Foreign Affairs regarding the Bioethics Convention and its Additional Protocols and their Signing and Ratification; April 29, 2005. www.etene.org.

[10] Law No. 1237 of 22 December 2006 on Assisted Fertilization. Finlands Förfatningssamling; December 27, 2006. p. 123742.

[11] Soini S. Personal communication.

[12] National Advisory Board on Health Care Ethics, Views of ETENE on the Memorandum of the Project Group Examining the Need to Revise Section 6 of the Patient Act; September 22, 2003. www.etene.org.

[13] Sheldon T. Finns defined patients' rights before Dutch. BMJ 1994;309:130-1.

[14] Loi no. 94-548 du 1er juillet 1994 relative au traitement de données nominatives ayant pour fin la recherche dans le domaine de la santé et modifiant la loi no. 78-17 du 6 janvier 1978 relative à l'informatique, aux fichiers et aux libertés; Loi no. 94-653 du 29 juillet 1994 relative au respect du corps humain; Loi no. 94-654 du 29 juillet 1994 relative au don et à l'utilisation des éléments et produits du corps humain, à l'assistance médicale à la procréation et au diagnostic prénatal (www.legifrance.gouv.fr).

[15] There was a Proposal of an Act Ratifying the Convention in 1998, But this Proposol was Never Worked Out Properly: projet de loi, autorisant la ratification de la convention pour la protection des droits de l'homme et la dignité de l'être humain à l'égard des applications de la biologie et de la médecine-convention sur les droits de l'homme et la biomédecine (No. 538 Sénat, 1997-1998, http://www.senat.fr/).

[16] Chirac J.Speech on the 32nd general conference of UNESCO. 2003.

[17] Fagniez PL. Cellules souches et choix éthiques. Rapport au Premier Ministre 2006:153.

[18] Fagniez PL. Cellules souches et choix éthiques. Rapport au Premier Ministre 2006:154.

[19] Garay A. The new French legislation relating to patients' rights and the quality of the health care system. European Journal of Health Law 2002;9:361-2; also published in Sanderfelt M, editor. Yearbook of European medical law 2005. Lidingo: The Institute of Medical Law; 2005. p. 127-43.

[20] Garay A. The new French legislation relating to patients' rights and the quality of the health care system. European Journal of Health Law 2002;9:361-2; also published in Sanderfelt M, editor. Yearbook of European medical law 2005. Lidingo: The Institute of Medical Law; 2005. p. 361-2.

[21] Legge 28 marzo 2001, no. 145, Ratifica ed esecuzione della Convenzione del Consiglio d'Europa per la protezione dei diritti dell'uomo e della dignità dell'essere umano riguardo all'applicazione della biologia e della medicina, www.italgiure.giustizia.it; Mori M, Neri D. Convention on 
Human Rights and Biomedicine. Journal of Medical Philosophy 2001;332.

[22] Place of deposit. Strasbourg: Council of Europe.

[23] Nys H, Stultiëns L, Borry P, Goffin T, Dierickx K, Patient rights in the EU Member States after the ratification of the Convention. Health Policy 2007. 83 (2-3): 223-35.

[24] Fineschi V, Turillazzi E, Cateni C. The new Italian code of medical ethics. Journal of Medical Ethics 1997:241.

[25] Italian Law 40/2004, no. 40, Gazzetta Ufficiale no. 45, February 24, 2004.

[26] Fenton RA. Catholic doctrine versus women's rights: the new Italian law on assisted reproduction. Medical Law Review 2006; $14: 78$.

[27] Judgment of the Italian Corte Costituzionale, 45/2005, Abstract in English, on the request seeking a total repeal of law no.40. http://solotesto.cortecostituzionale.it.

[28] Judgment 46/2005, 47/2005 and 48/2005.

[29] Birmontiene T. Health legislation in eastern European countries: the Baltic States. European Journal of Health Law 2004;11: 77.

[30] Birmontiene T. Health legislation in eastern European countries: the Baltic States. European Journal of Health Law 2004;11:81.

[31] Birmontiene T. Health legislation in eastern European countries: the Baltic States. European Journal of Health Law 2004;11:82-3.

[32] On the website of the Human Rights Education Associates an article regarding the problems with patient rights in Latvia "World Health Organization reports problems with patients' rights in Latvia", April 24, 2003 - was published. The report cited in this article was provided by Lars Fallberg, http://www.hrea.org.

[33] Fallberg L. Comments on the Latvian Draft Law on the Rights of Patients. http://phoebe.vm.gov.lv.

[34] Sulce L. Director of the Patients' Rights Office of Latvia, personal communication.

[35] Sulce L. Director of the Patients' Rights Office of Latvia, personal communication.

[36] The Latvian National Human Rights Office. On 1 January 2007 the new Ombudsman's Office on the basis of the Latvian National Human Rights Office has been established; January 3, 2007. www.vcb.lv.

[37] Projet de loi No. 5528 portant approbation de la Convention pour la protection des Droits de l'Homme et de la dignité de l'être humain à l'égard des applications de la biologie et de la médecine: Convention sur les Droits de l'Homme et la biomédecine, ouverte à la signature, à Oviedo, le 4 avril 1997, Chambres des députés, Session ordinaire, 2005-2006, www.chd.lu.

[38] Projet de loi No. 5528 [1]—Avis du Conseil d' Etat, Chambres des députés, Session ordinaire, 2005-2006, www.chd.lu.

[39] See on the issue of direct applicability: Nys H, Stultiëns L, Borry P, Goffin T, Dierickx K. Patient rights in EU Member States after the ratification of the Convention on Human Rights and Biomedicine. Health Policy 2007. 83 (2-3): 223-35.

[40] Projet de loi No. 5528 [2]—Dépêche de la secrétaire d'Etat aux relations avec le parlement au président de la Chambre des députés, Chambres des députés, Session ordinaire, 2005-2006, www.chd.lu.

[41] Nys H, Stultiens L. De rechten van de patiënt: verslag van een onderzoek naar de rechten van de patiënt in: België, Denemarken, Duitsland, Frankrijk, Luxemburg, Spanje en het Verenigd Koninkrijk. Staat van Gezondheidszorg 2006:55.

[42] Memorial A, Journal Officiel du Grand-Duché de Luxmebourg, 27 September 2005, www.legilux.public.lu.

[43] Loi du 19 novembre 2004 portant révision de l'article 11 de la Constitution, www.chd.lu.

[44] On November 19, 1996 the text of the Convention was approved by the countries of the Council of Europe. Beside Poland, the other countries that abstained vote on the final text were Belgium and Germany.

[45] Grzymkowska M. Personal communication.

[46] Dariusz Senatu, no. 1997. http://www.senat.gov.pl/K4/DOK/DIAR/05/0505.HTM.

[47] Ianeva E. Genetics and Society in Eastern Europe. http://www.biopolitics-berlin2003.org/.

[48] Nesteriwicz M, Bagińska E, Den Exter A. Poland. In: Nys $\mathrm{H}$, editor. International encyclopedia of medical law. London: Kluwer International; 2007. p. 38.

[49] Article 39a Code of Medical Ethics (adopted in 2004); Nesteriwicz M, Bagińska E, Den Exter A. Poland. In: Nys H, editor. International encyclopedia of medical law. London: Kluwer International; 2007. p. 38.

[50] Grzymkowska M. Who consulted the website of the Polish Parliament. Personal communication.

[51] The Polish Ombudsman for Human Rights. http://www.brpo.gov.pl.

[52] Baginska E. Health Care reforms in Poland. Medical Law 2004;23:746.

[53] Kozlowska KB. Charter of patients' rights with reference to European charter of patients' rights, obeying patients' rights in Poland. Ministry of Health 1998:8.

[54] Ross-Van Dorp C. Uitstel goedkeuring Verdrag inzake de rechten van de mens en biogeneeskunde. Nieuwsbank; maart 5, 2004. www.nieuwsbank.nl.

[55] Ross-Van Dorp C. Uitstel goedkeuring Verdrag inzake de rechten van de mens en biogeneeskunde. Nieuwsbank; maart 5, 2004. www.nieuwsbank.nl.

[56] Because of the fact that making a reservation would be in conflict with this decision whatever the result of the reservation would have been and that reservations only could be made at the moment of ratification, no reservation and no ratification was made.

[57] Roscam Abbing H. Recent developments in Health Law in the Netherlands. European Journal of Health Law 2006;13:134.

[58] Nys H, Dreezen I, Vinck I, Dierickx K, Dequeker E, Cassiman J-J. The Netherlands, genetic testing-patients' rights, insurance and employment. A survey of regulations in the European Union; 2002. p. 89.

[59] Birmontiene T. Changes in the Lithuanian Health Law and the Influence of the Netherlands Civil Code. European Journal of Health Law 2002;9:381-95.

[60] Government proposition 2002/03:50. Vetting the ethics of research involving humans, http://www.epn.se. 
[61] Rynning E. Personal communication.

[62] Genethique. La Suède autorise le clonage thérapeutique. Revue de presse, March 5, 2005. www.genetique.org.

[63] Frågor om förmyndare och ställföreträdare för vuxna. SOU 2004;112. http://www.regeringen.se.

[64] Rynning E. Personal Communication.

[65] Genetik, integritet och etik, SOU 2004;20. http://www. regeringen.se; Rynning E. Personal communication.
[66] Translated summary of the report by E. Rynning.

[67] Nys H, Dreezen I, Vinck I, Dierickx K, Dequeker E, Cassiman J-J. Sweden, Genetic Testing-Patients' rights, insurance and employment. A survey of Regulations in the European Union; 2002. p. 113.

[68] Fallberg LH. Patient rights in the Nordic Countries. European Journal of Health Law 2000;7:123-43. 